
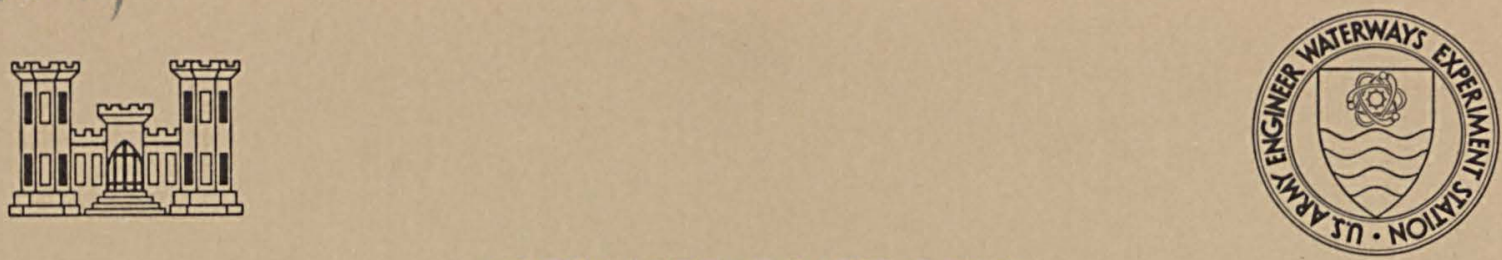

MISCELLANEOUS PAPER C-78-14

\title{
ACID ATTACK OF CONCRETE CAUSED BY SULFUR BACTERIA ACTION
}

by

Henry T. Thornton, Jr.

Concrete Laboratory

U. S. Army Engineer Waterways Experiment Station

P. O. Box 631, Vicksburg, Miss. 39180

\section{September 1978}

Final Report

Approved For Public Release; Distribution Unilimited

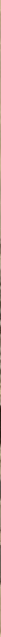

Prepared for U. S. Army Engineer District, Huntington

Huntington, W. Va. 25721 
Unclassified

SECURITY CLASSIFICATION OF THIS PAGE (Then Data Entered)

\begin{tabular}{|c|c|}
\hline REPORT DOCUMENTATION PAGE & $\begin{array}{c}\text { READ INSTRUCTIONS } \\
\text { BEFORE COMPLETING FORM }\end{array}$ \\
\hline \begin{tabular}{l|l} 
1. REPORT NUMBER & 2. GOVT ACCESSION NO. \\
Miscellaneous Paper C $-78-14$ &
\end{tabular} & 3. RECIPIENT'S CATALOG NUMBER \\
\hline \multirow[t]{2}{*}{$\begin{array}{l}\text { 4. TITLE (and Subtitle) } \\
\text { ACID A INTACK OF CONCRETE CAUSED BY SULFUR } \\
\text { BACTERIA ACTION }\end{array}$} & $\begin{array}{l}\text { 5. TYPE OF REPORT \& PEPIOD COVERED } \\
\text { Final report }\end{array}$ \\
\hline & 6. PERFORMING ORG. REPORT NUMBER \\
\hline $\begin{array}{l}\text { 7. AUTHOR(o) } \\
\text { Henry T. Thornton, Jr. }\end{array}$ & 8. CONTRACT OR GRANT NLMBER(B) \\
\hline $\begin{array}{l}\text { 9. PERFORMING ORGANIZATION NAME AND ADDRESS } \\
\text { U. S. Army Engineer Waterway EXPperiment Station } \\
\text { Concrete Laboratory } \\
\text { P. O. BOX } 631 \text {, Vicksburg, Miss. } 39180\end{array}$ & $\begin{array}{l}\text { 10. PROGRAM ELEMENT, PROJECT, TASK } \\
\text { AREA \& WOFK UNIT NUMERS }\end{array}$ \\
\hline \multirow{2}{*}{$\begin{array}{l}\text { 11. CONTROLLING OFFICE NAME AND ADDRESS } \\
\text { U. S. Army Engineer District, Huntington } \\
\text { P. O. BOX } 2127 \\
\text { Huntington, W. Va. } 25721\end{array}$} & $\begin{array}{l}\text { 12. REPORT DATE } \\
\text { September } 1978\end{array}$ \\
\hline & $\begin{array}{l}\text { 13. NUMBER OF PAGES } \\
24\end{array}$ \\
\hline \multirow[t]{2}{*}{ 14. MONITORING AGENCY NAME ADDRESSYIf difforent from Controlltind Offico) } & $\begin{array}{l}\text { 15. SECURITY CLASS. (of this roport) } \\
\text { Unclassified }\end{array}$ \\
\hline & $\begin{array}{l}\text { 15a. DECLASSIFICATION/DOWNGRADING } \\
\text { SCHEDULE }\end{array}$ \\
\hline
\end{tabular}

Approved for public release; distribution unlimited.

17. DISTRIBUTION STATEMENT (of the abetract on tored in Block 20, it different from Report)

18. SUPPLEMENTARY NOTES

CTIAC Report No. 28

19. KEY WORDS (Continue on reverse aldo if necessny and ldontlfy by block number)

acid attack

bacteriological tests

dissolved oxygen

sulfides

chemical tests

hyärogen sulfide

sulfur bacteria

concrete deterioration physical tests themal stratification

corrosive process sulfates

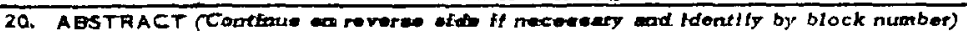

The fact that concrete constitutents are susceptible to attack and decomposition by acids is no new topic for discussion. The process by which certain scnera of anaercic bacteria produce acids has also been documented. However, most of the literature linking these phenomena with the deterioration of concrete structures has been addressed primarily to problems associated with concrete sewer pipes, and most of the reporting was done in the $1950^{\circ} \mathrm{s}$. This paper was extracted from a report of a recent investigation performed for the U. S. Army Engineer 
20. Abstract. (Continued)

District, Huntington, into the combined effects of these phenomena on strucural concrete. The investigation starts with the manifestation of the problem, i.e., the concrete in the outlet tunnels of two lakes being reduced to a "mush" consistency to depths up to $1-1 / 4 \mathrm{in}$. (approximately $32 \mathrm{~mm}$ ) over a period of about 5 years. The program of investigation includes a literature review, sample collection, and physical, chemical, and bacteriological tests. It is concluded that the deterioration is due to acid attack and is the final stage of a corrosive process caused by sulfur bacteria action. Immediate and long range remedial measures are suggested for consideration for implementation at both sites. Attention is drawn to the fact that undetected deterioration of other concrete structures may be in progress. 
This investigation was conducted for the U. S. Army Engineer District, Huntington. It was performed by the U. S. Army Engineer Waterways Experiment Station (WES) Concrete Laboratory (CL) personnel under the direction of Mr. Bryant Mather, Chief, CL, Mr. Leonard Pepper and Mrs. Katharine Mather, former Chief and Chief, respectively, of the Engineering Sciences Division, and Mr. John M. Scanion, Chief, Engineering Mechanics Division. Mr. Alan D. Buck was responsible for the petrographic work and $\mathrm{Mr}$. Tony B. Husbands directed the chemical tests. Mr. Henry T. Thornton, Jr., was project leader of this investigation and the author of this report.

A report was issued to the sponsor in August 1977 as WES Miscellaneous Paper C-77-9. Funds available for the Concrete Technology Information Analysis Center (CTIAC) were made available for the preparation of a paper based on this work so as to facilitate technology transfer. The paper was approved by the District Engineer, Huntington District, and the Office, Chief of Engineers, and accepted for priblication by the American Concrete Institute. This is CTIAC Report No. 28.

Directors of the WES during the conduct of this investigation and the preparation and publication of the report were COL G. H. Hilt, CE, and COL J. L. Cannon, CE. Technical Director was Mr. F. R. Brown. 


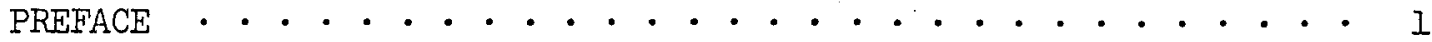

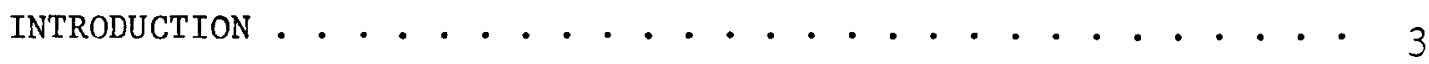

LITERATURE REVIEW, SULFUR BACTERIA . • • . • • • . • • • . • . 4

Description and Life Cycle . . . . . . . . . . . . . 4

The Corrosion Process . . . . . . . . . . . . . . 4

Effects of the Corrosion Process . . . . . . . . . . . . 5

Remedial Measures . . . . . . . . . . . . . . . . 6

DESCRIPTION AND CONDITION OF OUTLET TUNNELS . . . . . . . . . . . 7

Description . . . . . . . . . . . . . . . . . . . . 7

Condition . . . . . . . . . . . . . . . . . . . . . 7

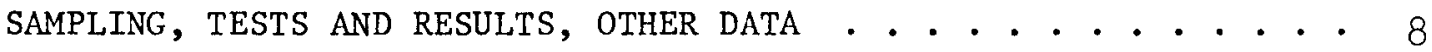

Sampling . . . . . . . . . . . . . . . . . . . . . 8

Tests and Results . . . . . . . . . . . . . . . . . 8

Other Data. . . . . . . . . . . . . . . . . . . . . 10

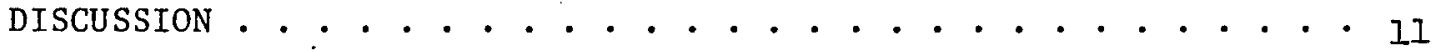

Concrete Quality . . . . . . .............. . . II

Water Quality . . . . . . . . . . . . . . . . . . . II

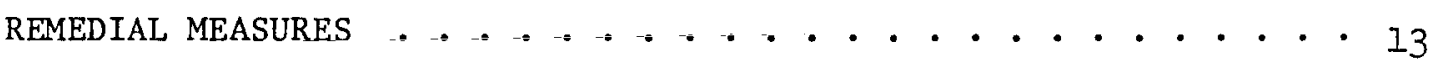

Long Range . . . . . . . . . . . . . . . . . . . . 13

Immediate . . . . . . . . . . . . . . . . . . . 14

CONCLUSIONS AND RECOMMENDATIONS . . . . . . . . . . . . . . 15

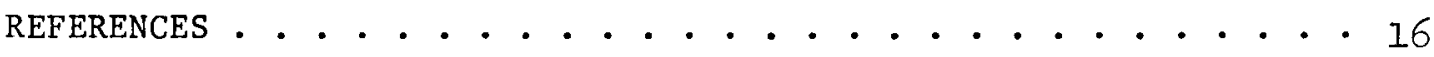

FIGURES 1-8 
ACID ATTACK OF CONCRETE CAUSED

BY SULFUR BACTERIA ACIION

INTRODUCTION

Pledmont and Clendening Lakes are two of a system of projects designed to provide flood control, recreation, and water conservation in the Muskingum Watershed in southeastern Ohio. Piedmont and Clendening Lakes were constructed in 1937 and 1936, respectively, and cover approximately 2300 and 1800 acres (931 and 728 hectares), respectively. Periodic inspection reports on these two projects in May of 1970 and June of 1974, and interim inspections in December 1976, documented the progress of inordinate deterioration of the concrete in the outlet tunnels. During this time the cement paste was decomposed into a "mushy" substance to depths up to 1-1/4 in. (approximately $32 \mathrm{~mm}$ ) exposing and dislodging aggregate. A preliminary study of the periodic inspection reports and other available information on the projects indicated problems of a unique nature and dictated some deviation from the methodology developed over the years for varfous types of condition surveys. The program of investigation adopted for this project was designed to provide information that would be relevant in answering the following questions:

a. What is the mechanism causing the deterioration of the concrete in the outlet tunnels?

b. Do the characteristics of the concrete reinforce this mechanism or contribute to the deterioration?

c. What remedial measures are available and which of them are feasible and applicable in this particular situation? 
The testing program and means by which data were collected are as follows:

a. An extensive literature review into the cause, effect, and remedial measures concerning the mechanism of concrete corrosion caused by sulfur bacteria.

b. Sampling at each site, including water, deterioration products, and concrete cores.

c. Tests for physical properties of concrete, characteristics of deterioration products, water quality, and identification of sulfate-reducing bacteria.

d. Obtaining other pertinent data and information.

\section{LITERATURE REVIEW, SULFUR BACTERIA}

Most of the literature addressing the problem of deterioration of concrete by bacterial action evolved because of the great impact of this corrosive mechanism on concrete sewer systems. This is a serious problem and, as Rigdon and Beardsley ${ }^{2}$ observed, occurs mainly in warm climates such as prevail in California, Australia, and South Africa.

\section{Description and Life Cycle}

Sullfur-reducing bacteria belong to the genus of bacteria that obtain the energy for their life processes from the oxidation of some element other than carbon, such as nitrogen, sulfur, or iron. ${ }^{2}$ Some of them are able to reduce the sulfates which are present in natural waters and produce hydrogen sulfide as a waste product. These bacteria, as stated by Wetzel, ${ }^{3}$ are anaerobic. Another group takes the reduced sulfur and oxidizes it back to sulfuric acid. The genus Thiobacillus is the sulfur bacteria which is most destructive to concrete. It has a remarkable tolerance of acid. Concentrations of sulfuric acid as great as 5 percent do not completely inhibit their activity.

\section{The Corrosion Process}

Rigdon and Beardsley ${ }^{2}$ and Forrester ${ }^{4}$ described the process of corrosion of concrete by bacterial action in almost identical terms. Sulfur bacteria are likely to be found wherever warmth, moisture, and reduced 
compounds of sulfur are present. Certain conditions must prevali before the second group of sulfur bacteria mentioned above can become established on the concrete surface and begin the process of corrosion. Sufficient moisture must be present to prevent the desiccation of the bacteria. There must be adequate supplies of hydrogen sulfide, carbon dioxide, nitrogen compounds, and oxygen. In addition, soluble compounds of phosphorus, fron, and other trace elements must be present in the moisture film.

Newly made concrete has a strongly alkaline surface with a pH of about 12. No species of sulfur bacteria can live in so alkaline an environment. Therefore the concrete is temporarily free from bacterially induced corrosion. Natural carbonation of the free lime by the carbon dioxide in the air slowly drops the $\mathrm{pH}$ of the concrete surface to nine or 1ess. At this level of alkalinity the sulfur bacteria Thiobacillus thioparus, using hydrogen sulfide as a substrate, generate thiosulfuric and polythionic acid. The pH of the surface moisture steadily declines, and at a pH of about five the Thiobacillus concretivorus begin to proliferate and produce high concentrations of sulfuric acid, dropping the $\mathrm{pH}$ to a level of two or less. The destructive mechanism in the corrosion of the concrete is the decomposition of the calcium silicates and aluminates in the cement paste by the sulfuric acid.

\section{Effects of the Corrosion Process}

Reference 5 cites examples of corrosion damage such as: a steel rising main which dissolved in 18 months; concrete trunk sewers stripped beyond the reinforcement within 10 years; numerous cases of asbestos cement pipes (some with protective coatings) eaten away above the sewage line in 5 to 10 years; machinery and fittings being attacked-in one case, cast iron penstocks at a pumping station are reported to have totally disappeared in 6 to 7 years. All this damage was attributed to bacterial action of one type or other. Woods ${ }^{6}$ reported a disposal well in Texas suddenly developed a high head after previously operating under vacuum; a fresh-water well in California suddenly caused plugged filters ahead of a demineralizer unit (the clogging material was identified as 
elemental sulfur); a water supply system in Kansas suddenly became fouled with iron deposits; deionizing equipment in Arizona became ineffective because of resin poisoning due to leaching of iron from the formation. Each malfunction resulted from some type of bacterial action.

\section{Remedial Measures}

Parker $^{7}$ outlined 17 ways in which the corrosion process may be interrupted and result in the damage being halted.

\section{Discharge of sulfides}

Eliminate trade wastes containing sulfides.

Hydrogen sulfide generation

a. Reduce the concentration of sulfates.

b. Partially purify by sedimentation, etc.

c. Dose with chemicals to raise oxidation-reduction potential.

d. Aerate by forcing air into bottom end of rising mains.

e. Treat with chlorine to oxidize any hydrogen sulfide present and to prevent further generation.

f. Remove slime and silt where hydrogen sulfide is generated.

g. Increase the rate of flow.

Emission of hydrogen sulfide

a. Reduce turbulence of flow.

b. Precipitate hydrogen sulfide by adding heavy metal salts.

c. Add alkalies to reduce the undissociated hydrogen sulfide.

d. Run sewer full, thereby eliminating atmosphere.

Rate of hydrogen sulfide

fixation on concrete

a. Ventilate to remove hydrogen sulfide and lower humidity.

b. Flush walls periodically above waterline to ellminate environment of proliferation.

c. Use a more acid resistant concrete.

d. Dose atmosphere with ammonia to neutralize acid.

e. Provide protective lining for concrete. 


\section{DESCRIPTION AND CONDITION OF OUTLET TUNNELS}

\section{Description}

The outlet tunnel at Piedmont Lake is $670.5 \mathrm{ft}$ (approximately $204 \mathrm{~m}$ ) long, $10 \mathrm{ft}$ (approximately $3 \mathrm{~m}$ ) in diameter, and has a grade of 0.26 percent. The Clendening Lake tunnel is $498 \mathrm{ft}$ (approximately $152 \mathrm{~m}$ ) 1ong, $8 \mathrm{ft}$ (approximately $2.4 \mathrm{~m}$ ) in diameter, and has a grade of 0.372 percent. At the downstream end of each tunnel there is a rising invert with a 2-ft (approximately $0.6-\mathrm{m}$ ) wide slot. These rising inverts back water up in the tunnels when operating at normal water release. The back-up water depth is approximately $3 \mathrm{ft}(1 \mathrm{~m})$ at $\mathrm{Clendening}$ and $4 \mathrm{ft}(1.2 \mathrm{~m})$ at Piedmont. After the water flows over the invert or through the slot, it passes through the stilling basin and continues downstream. About 50 percent of the time, during a typical year, water from the reservoir enters the tunnels through siphons which function to maintain minimum pool (approximately $34 \mathrm{ft}(10 \mathrm{~m})$ of water) in the reservoirs. Although the siphoning usage is controlled at higher elevations, the water drawn from the reservoir by the siphons comes from very near the bottom.

\section{Condition}

The water in the stilling basins and in the streams at both projects was of a pale blue color with a white foam floating on it. The lines of normal flow were clearly discernible by the water marks on the sides of the tunnels. About one-third of the way into the tunnels the deterioration became evident above the normal flow lines (FIgure 1). In the vicinity of the gate-transition areas the deterioration was more pronounced (Figure 2). The conditions inside the tunnels were very similar to those described by Parker ${ }^{7}$ when relating to acjd attack in concrete sewers.

Before access to the tunnels was granted (September), the air inside was checked for methane, hydrogen sulfide, and other toxic gases by personnel from the Mine Enforcement Safety Administration. Hydrogen sulfide gas was present at a level of five parts per million in the air in Clendening tunnel. Although this is not considered to be a hazardous level, 
the presence of hydrogen sulfide gas in the tunnel was noteworthy. No other toxic or corrosive gases were found in either tunnel. However, operations personnel at both sites reported that during July, August, and September a very strong hydrogen sulfide odor prevails. Piedmont personnel reported that during this period the white-painted signs near the tunnel portal turn black, and that the black film disappears in the fall when the odor subsides. Piedmont tunnel had 3 to $4 \mathrm{hr}$ to ventilate prior to measurements for toxic gas detection.

SAMPLING, TESTS AND RESULTS, OTHER DATA

\section{Sampling}

Water samples, deterioration products, and concrete cores were taken from each tunnel to provide specimens for physical, chemical, and biological tests. Three water samples were taken from each tunnel--an unstabilized sample for sulfate tests, a sample stabilized with zinc acetate for sulfide tests, and a sample to test for sulfate-reducing bacteria. All water samples were taken as near to the gates as possible in order to avoid contamination and aeration.

Two samples of deterioration products were scraped from the roof of each tunnel in the severely damaged areas. One sample from each tunnel was returned to the laboratory as scraped from the roof; the other was added to water containing zinc acetate for sulfide stabilization.

Two 4-1n. (approximately 100-mm) diameter concrete cores were taken from each tunnel in September 1975. One core came from near the long1tudinal midpoint of each tunnel, and one came from near the sluice gates in each tunnel. All cores were taken from a helght of about $3 \mathrm{ft}$ ( $1 \mathrm{~m}$ ) up on the tunnel walls.

\section{Tests and Results}

Ultrasonic velocity measurements and unconfined compressive strength tests were performed on the concrete cores returned to the Concrete Laboratory in accordance with $C R D-C 51-72^{8}$ and $C R D-C$ 27-65. 8 The average 
velocity and strength of the Piedmont cores were 15,180 fps (4627 m/s) and 9515 psi ( $66 \mathrm{MPa}$ ), respectively, with very little variation between the upstream core and the midpoint core. There were two pieces of each core from clendening tunnel. The average velocity and strength for the upstream cores were $15,105 \mathrm{fps}(4604 \mathrm{~m} / \mathrm{s})$ and $7745 \mathrm{psi}(53 \mathrm{MPa})$. The midpoint cores averaged $15,150 \mathrm{fps}(4618 \mathrm{~m} / \mathrm{s})$ and $6245 \mathrm{psi}$ (43 MPa). The Piedmont cores were considerably stronger than those of clendening, but the velocities were all very nearly the same. These data indicate no reason to suspect poor concrete quality.

Velocity measurements were also made through the piers located just downstream of the gates in each tunnel. These piers were in the splash area where water enters the tunnels and exhibited considerable loss of mortar and aggregate where the deterioration product had been washed away. The surfaces were rough due to exposed aggregate, but did not prohibit velocity measurements. Two readings were made in each pier in each tunnel. One velocity on pier No. 2, Piedmont, was low, but this is probably caused by surface irregularities. The strength of the concrete represented by these velocities is probably $6000 \mathrm{psi}$ ( $41 \mathrm{MPa}$ ) and above.

Appropriate petrographic methods were used to test the concrete cores and deterioration products from the tunnels. Miscellaneous Paper No. C $-77-9^{1}$ includes a complete petrographic report that contains a detalled description of the cores and the deterioration products, the locations from which they came, and an explanation of test procedures. Some general findings stated in the petrographic report are:

a. The mechanism of deterioration is not sulfate attack because there was no ettringite present (a reaction product of sulfate attack), and sulfate attack would be more widespread.

b. There are indications of some form of acid attack because the acid-soluble carbonates in the aggregate are missing.

c. Attack by acid water is not indicated, since all the deterioration occurs above the waterline.

Tests for sulfate content in the water of the two outlet tunnels using the turbidimetric method ${ }^{9}$ revealed levels of $499 \mathrm{mg} / \ell$ at Piedmont and $311 \mathrm{mg} / \mathrm{l}$ at clendening. Sulfides were shown by tests $(228 \mathrm{~A})^{10}$ to be present in Piedmont and Clendening waters in the amounts of $11.5 \mathrm{mg} / \mathrm{l}$ and 
$7.2 \mathrm{mg} / \mathrm{l}$, respectively. The test for sulfate-reducing bacteria, $\mathrm{D} 993-58,9$ which entails growing the bacterla in a culture medium, was positive for the Pledmont Lake sample. The samples were collected in January, during the mixing cycle of the lake, so it is not surprising that the clendening sample was negative.

\section{Other Data}

Available water quality data from samples taken over the years from various locations in Piedmont and Clendening Lakes included water temperatures, $\mathrm{pH}$, dissolved oxygen content, and sulfate content at various water depths. The $\mathrm{pH}$ and sulfate content taken from the composite statistical summaries for the two lakes are as follows:

\begin{tabular}{|c|c|c|c|c|c|c|c|}
\hline & \multicolumn{3}{|c|}{$\mathrm{pH}$} & \multicolumn{3}{|c|}{ Sulfate, $\mathrm{mg} / \mathrm{l}$} & \multirow{2}{*}{$\begin{array}{c}\text { Reporting } \\
\text { Period } \\
\end{array}$} \\
\hline & Mean & Max & Min & Mean & Max & Min & \\
\hline $\begin{array}{l}\text { Piedmont* } \\
\text { Clendening** }\end{array}$ & $\begin{array}{l}7.9 \\
7.8\end{array}$ & $\begin{array}{l}8.9 \\
9.2\end{array}$ & $\begin{array}{l}7.1 \\
6.6\end{array}$ & $\begin{array}{l}526 \\
314\end{array}$ & $\begin{array}{l}700 \\
431\end{array}$ & $\begin{array}{l}420 \\
250\end{array}$ & $\begin{array}{l}7 / 73-9 / 76 \\
8 / 74-9 / 76\end{array}$ \\
\hline
\end{tabular}

* Maximum depth $30 \mathrm{ft}$ (approximately $9 \mathrm{~m}$ ).
** Maximum depth $35 \mathrm{ft}$ (approximately $11 \mathrm{~m}$ ).

The fact that the overall thermal structure and dynamics of some lakes undergo seasonal changes (as discussed by Reid), 11 is relatively well. known. During winter the temperature of the water is relatively uniform from surface to bottom due to surface water becoming dense, moving to the bottom and displacing water which has become relatively warmer. During the summer this natural mixing diminishes and any vertical heat transfer must be accomplished, mainly, by wind action. ${ }^{11}$ Thermal stratification can develop, causing a thermal resistance to mixing, which ultimately can lead to the development of a thermocline. A thermocline is defined as "the plane of maximum rate of decrease in temperature." In many lakes the zone below the thermocline, designated the hypolimnion, becomes devoid of dissolved oxygen and high in carbon dioxide. 11 In the fall, normal mixing due to increased relative density of surface water starts to break down the stratification. When this occurs, vertical circulation is restored, vertical temperature gradients diminish, and dissolved oxygen becomes more evenly distributed from surface to bottom of the lake. A 
review of the water quality data indicates that seasonal conditions similar to those fust described exist at Piedmont and Clendening Lakes.

Figures 3-8 give temperature and dissolved oxygen profiles with water depth for Piedmont and Clendening Lakes. July and August 1976 data are presented to show typical conditions during the summer months. September 1976 data are given to show how conditions begin to change in the fall. These data were obtained from collection points in the deep parts of the lakes near the dams, and show that dissolved oxygen depletion occurs in the summer months at depths of 20 to $22 \mathrm{ft}$ (6 to $7 \mathrm{~m}$ ) and below at Pledmont, and at depths of around $15 \mathrm{ft}$ (approximately $5 \mathrm{~m}$ ) and below at Clendening Lake. Plots of data (Figures 5 and 8 ) collected in the early fall illustrate the return of uniform distribution of temperature and dissolved oxygen with depth due to natural cold-weather mixing action. A study of all available data indicates that dissolved oxygen depletion begins in Piedmont Lake in early June and lasts into September, when stratification starts to break down. There were insufficient data to determine when this cycle starts at clendening, but mixing action starts in September.

\section{DISCUSSION}

Concrete Quality

The results of the ultrasonic velocity measurements, unconfined compressive strength tests, and petrographic examinations of the concrete cores indicate that the quality of the concrete in the outlet tunnels at Piedmont and Clendening Lakes is good, and that the mechanism causing the deterioration did not originate from materials of a deleterious nature or reactions within the concrete. Velocity measurements made through the concrete piers near the sluice gates in each tunnel indicate that the quality of the concrete in the piers in each tunnel is as good as that of the concrete cores from the respective tunnels.

\section{Water Quality}

The $\mathrm{pH}$ of the water at Piedmont and Clendening Lakes does not contribute 
to the deterioration of the concrete in the outlet tunnels. However, the respective sulfate 1 evels of $500 \mathrm{mg} / \mathrm{l}$ and $300 \mathrm{mg} / \mathrm{l}$, and respective sulfide levels of $11.5 \mathrm{mg} / \ell$ and $7.2 \mathrm{mg} / \ell$ are high and could lead to deterforation of environmental quality downstream. Some sources of sulfur compounds to natural waters are rocks, fertilizers, atomospheric transport, and organic wastes. ${ }^{3}$ The relative contributions of these sources vary with the regional lithology, agricultural application of sulfate-containing fertilizers, the proximity of atmospheric sources, and the type of Industrial wastes dumped Into inflowing streams. Paperproducing industries and strip-mining operations are common sources of sulfate-rich by-products. A brief study of available information indicates that strip-mining operations are the major contributors of sulfate to Piedmont Lake.

The high concentrations of hydrogen sulfide in Pledmont and clendening Lakes during the summer are apparently the result of the decomposition of organic matter by bacterial metabolism. The summer stratification of the water and subsequent depletion of dissolved oxygen in the hypolimnion provide the required environment for the bacterlal reduction of sulfates and release of hydrogen sulfide. Stuiver ${ }^{12}$ reports that the rate of reduction of sulfates in anoxic reglons, or regions partly devoid of oxygen, is 10 times faster than in the fully aerobic region. He also found that horizontal diffusion was sufficient to transport sulfates to the surrounding sediments, thereby providing organic substrates for bacterial metabolism in the hypolimnion and sediments. The sulfide is stored in the water and in the sediment. During a 4-month period, as much as $1 \mathrm{mg}$ was stored per $\mathrm{cm}^{2}$ of sediment in one pond. The escape of hydrogen sulfide to the atmosphere by diffusion or gas bubbles was very small.

With accumulations of hydrogen sulfide on and near the bottoms of the lakes, all that is necessary to start the corrosion process is to get the hydrogen sulfide into the crowns of the tunnels. This is obviously accomplished by the normal operation of the siphons and gates, since they both draw water from near the bottom of the lakes. As the water enters the tunnels the turbulence causes hydrogen sulfide to be released into 
the tunnel air and the corrosion process described previously begins. Factors that substantiate these postulations are:

a. Acid water is not the deteriorating agent of the concrete.

b. The sulfate-rich, oxygen-free hypolimnion during summer stratification provides the environment for bacterial proliferation.

c. The sulfide contents of the water samples were very high.

d. The water entering the tunnels is drawn from the hypolimnion where hydrogen sulfide is stored.

e. Sulfate-reducing bacteria were cultured and identified from a sample of Piedmont Lake water.

f. The conditions in the tunnels are favorable for bacteria proliferation and the damage in the tunnels is similar to that described in the literature.

g. Physical tests show the intact concrete to be of good quality, and also indicate that acid attack is the deterioration mechanism.

REMEDIAL MEASURES

\section{Long Range}

The most desirable remedy would be one which would eliminate the entire process. To accomplish this, the high concentrations of sulfates in the lakes must be eliminated. Finding and/or eliminating the sulfate source or sources may be impossible or impractical, especially if strip mining operations are the major contributors. The next point of interruption of the process is reducing or eliminating the hydrogen sulfide generation or oxidizing it by chemical treatment as it is generated. Dosing with chemicals can be costly and problematic. Of all the possibilities, aeration or destratification seems to be the most practical means of inhibiting hydrogen sulfide production in the lakes.

Circulation and aeration by mechanical means is a common method of increasing the use potential of lakes. The basic objective is, usually, to improve the dissolved oxygen conditions. ${ }^{13}, 14$ The two categories of aeration are total aeration and hypolimnetic aeration. Total aeration effects complete destratification and hypolimnetic aeration brings deep water up for oxygenation and returns it without disrupting thermal 
stratification. Other techniques used are deepening, dredging, drawdown and sediment consolidation, harvesting, etc. ${ }^{13}$ There are, of course, problems associated with each technique.

\section{Immediate}

There are a variety of ways to interrupt the concrete deterioration process in the tunnels. Of those mentioned previously under remedial measures, ventilation and wall flushing seem to be the most practical and, probably, the most economical. Ventilation could be accomplished by forcing air through the entire lengths of the tunnels, or by venting with a series of shafts bored through the crown, or both. Some experimentation would be necessary to determine the flow of air through the tunnel or the number of vents that would be required to effectively reduce the deterforation. The effectiveness of flushing the walls to remove the substrates necessary to sustain bacteria metabolism would also have to be investigated.

Another measure that should be given serious consideration is that of raising the siphon intake elevation. Looking at the plotted data it seems that siphoning the water from Pledmont Lake from the upper $20 \mathrm{ft}$ (approximately $6 \mathrm{~m}$ ) and from Clendening Lake above $15 \mathrm{ft}$ (approximately $5 \mathrm{~m})$ could possibly eliminate the injection of hydrogen sulfide into the tunnels through the siphons. These levels may change gradually during the summer, but periodic samples of water could serve as a depth gulde. Gate operations would still inject sulfide, but minimal operation may reduce the sulfide to a harmless level. It may be necessary to supplement shallow siphoning with some degree of ventilation.

The measures outlined in the two preceding paragraphs may serve to decrease the effects of the corrosive process in the tunnels, but the causative factors will remain in the lakes if remedial measures are not implemented. The sulfate and sulfide concentrations will remain high, and the semiannual periods of dissolved oxygen depletion caused by thermal stratification will continue. Although an overall oxygenation problem may never arise within the lakes, the potential for injecting water with high sulfate-sulfide contents into the fresh-water stream will remain. 
After an evaluation of the summation of test results and other accumulated data and information pertaining to this investigation, it is concluded that the deterioration of the concrete in the outlet tunnels of Piedmont and Clendening Lakes is most likely due to acid attack and is the final stage of a corrosive process caused by sulfur bacteria action. The process starts with the production, by bacteria, of hydrogen sulfide from the sulfate-rich water in the lake, and by organic decomposition in the sediment. The hydrogen sulfide passes through the siphons and gates and is released into the atmosphere in the gate-transition area due to the turbulence of the water. The hydrogen sulfide collects in the crown of the tunnel in concentrated amounts for some distance down the tunnel, is oxidized into sulfuric acid by concretivorus bacteria, and the constituents of the cement paste are decomposed by the acid. Physical mechanisms such as freezing and thawing and hydraulic washing probably aid the corrosive process.

It is recommended that remedial measures such as ventilation, flushing, or raising siphon intakes be implemented as soon as determinations have been made concerning the applicability of each measure to the probiem. Considering the emphasis placed on energy conservation and increased productivity within most energy sources, it seems unlikely that stripmining operations will cease or diminish in the near future. Therefore, if strip-mining operations are the major contributors of sulfates to Piedmont and Clendening Lakes, the corrosion process caused by the action of sulfur bacteria will have to be interrupted at some point after the sulfates have entered the lake water.

Because of its subtle nature, this type of problem could go undetected for many years. For this reason, and because of the potential impact on structural integrity and environmental considerations, it seems appropriate to point out that there may be other structures deteriorating that have gone undetected. Rigdon and Beardsley ${ }^{2}$ observed that most sewers in the southern United States meet the conditions for bacteria proliferation. 
The results of this investigation indicate that this problem is not necessarily restricted to certain structures or regions.

\section{REFERENCES}

1. Thornton, H. T., Jr., Acid Attack of Concrete Caused by Sulfur Bacteria Action, Piedmont and Clendening Lakes outlet Tunnels, Muskingum Watershed, Ohio, Miscellaneous Paper No. C-77-9, U. S. Army Engineer Waterways Experiment Station, Vicksburg, Miss., Sep 1977, $41 \mathrm{pp}$.

2. RIgdon, J. H., and Beardsley, C. W., "Corrosion of Concrete by Autotrophes," Corrosion - National Association of Corrosion Engineers, Vol 14, Apr 1958, p 60.

3. Wetzel, R. G., Limnology, W. B. Saunders Company, PhIladelphia, London, Toronto, 1975, p 271.

4. Forrester, J. A., An Example of Concrete Corrosion Induced by Sulphur Bacterla in a Sewer, Technical Report No. TRA/320, Cement and Concrete Association, 52 Grosvenor Gardens, London SWl, Jul 1959, 12 pp.

5. Appleton, B., "Acid Test for Middle East Drain Brains," New Civil Engineer; No. 181, London, 19 Feb 1976, pp 20-23.

6. Woods, G. A., "Bacteria: Friends or Foes?," Chemical Engineering, Vo1 8, No. 6, 5 Mar 1973, pp 81-84.

7. Parker, C. D., Mechanics of Corroston of Concrete Sewers hy Hydrogen Sulfide," Sewage and Industrial Waste, Ve1 23, No. 12, Lancaster, Pa., Dec 1951, pp 1477-1485.

8. U. S. Army Engineer Waterways Experiment Station, CE, Handbook for Concrete and Cement, with quarterly supplements, Vicksburg, Miss., Aug 1949.

9. ASTM Manual on Industrial Water and Industrial Waste Water, $2 d$ ed., American Society for Testing and Materials, Philadelphia, Pa., 1966, pp 263, 350 .

10. American Public Health Association, Standard Methods for Examlnation of Water and Wastewater, 13th Ed., Washington, D. C., 1971, p 552 .

11. Reid, G. K., Ecology of Inland Waters and Estuaries, Van Nostrand Reinhold Co., New York, Cincinnati, Toronto, London, Melbourne, 1961, p 110. 
12. Stuiver, M., The Sulphur Cycle in Lake Waters during Thermal Stratification, Geochimica et Cosmochimica Acta, Vol 31, 1967, pp 2151-2167.

13. Survey of Lake Rehabilitation Techniques and Experiences, Technical Bulletin No. 75, Department of Natural Resources, Madison, Wis., 1974, p 18 .

14. Aeration as a Lake Management Technique, Technical Bulletin No. 87, Wisconsin Department of Natural Resources, Madison, Wis., 1975, p 2. 


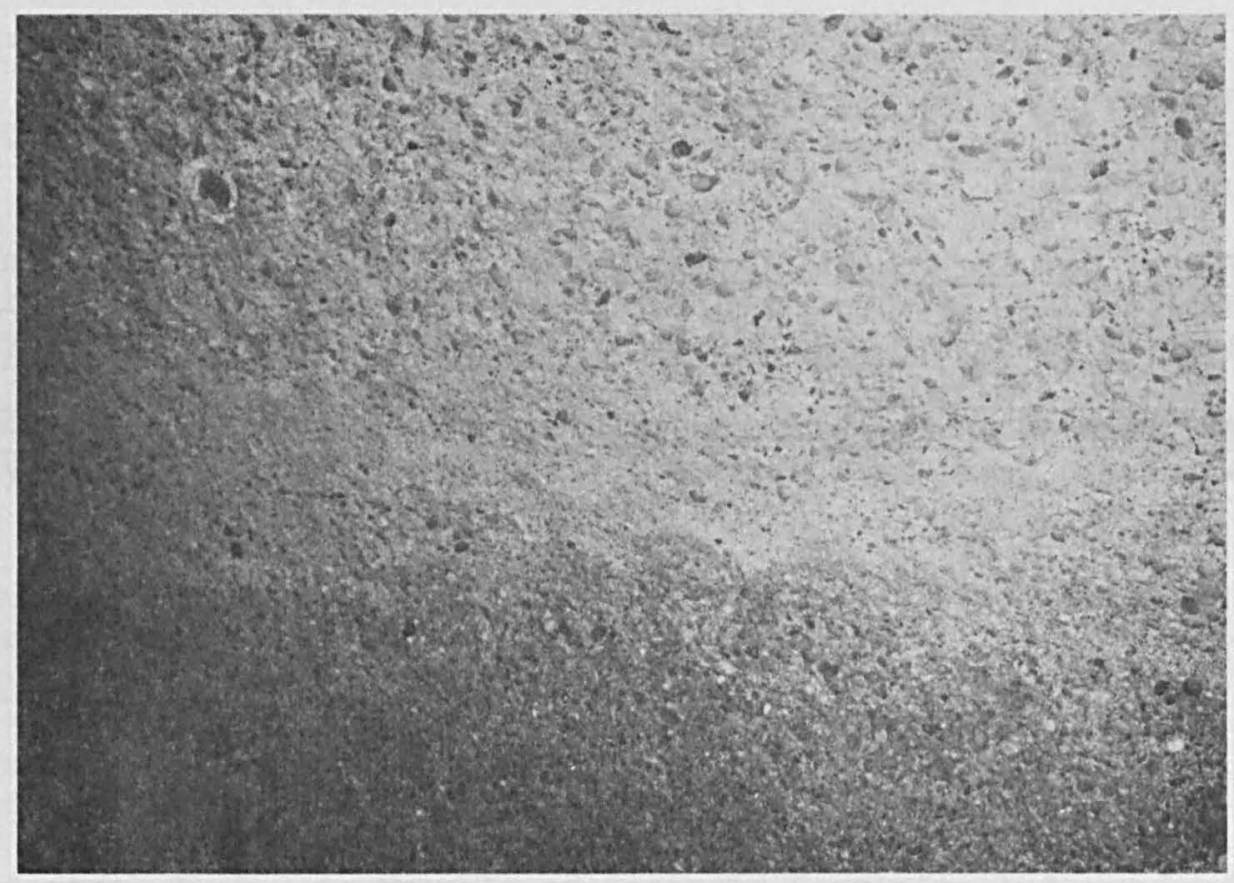

Figure 1. Clendening Lake, deterioration above normal flow line

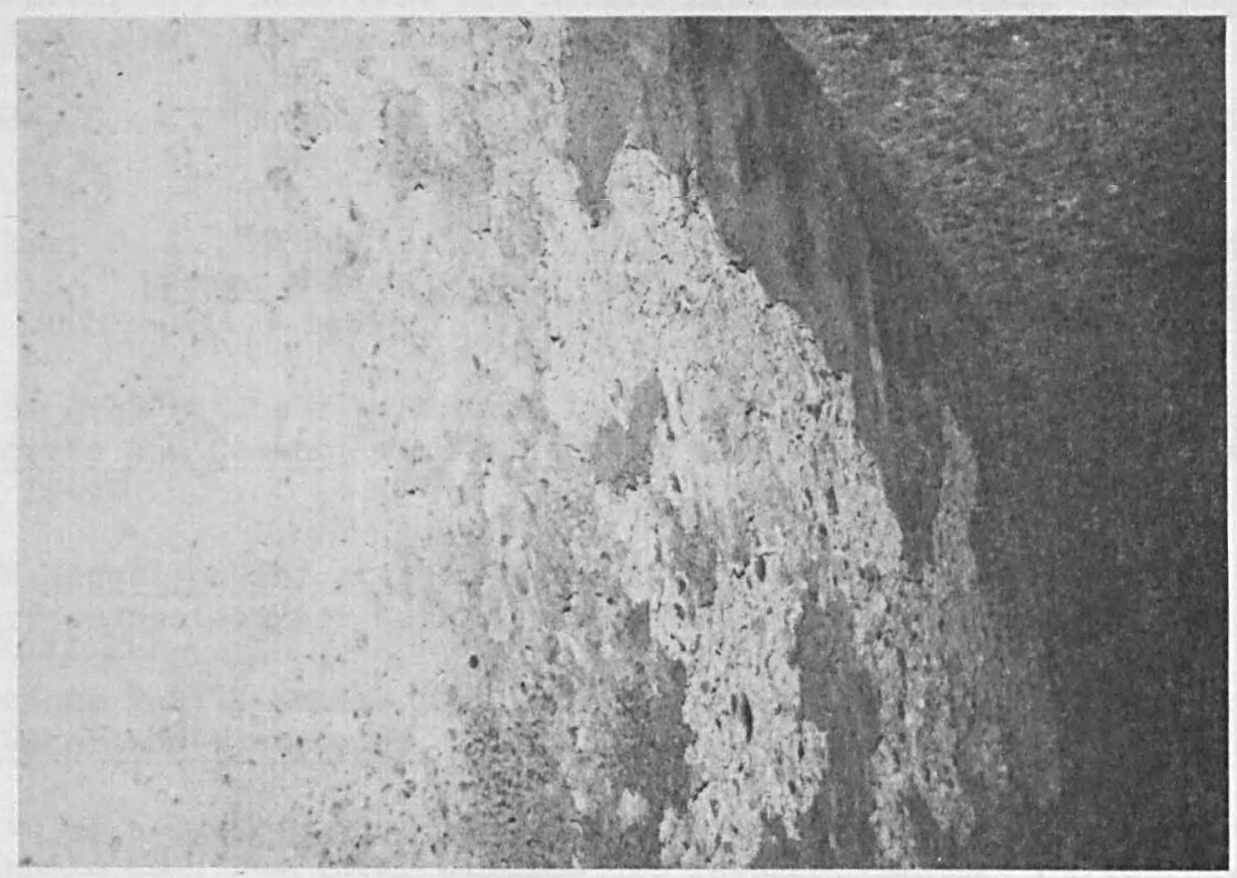

Figure 2. Clendening Lake, deterioration near gates 


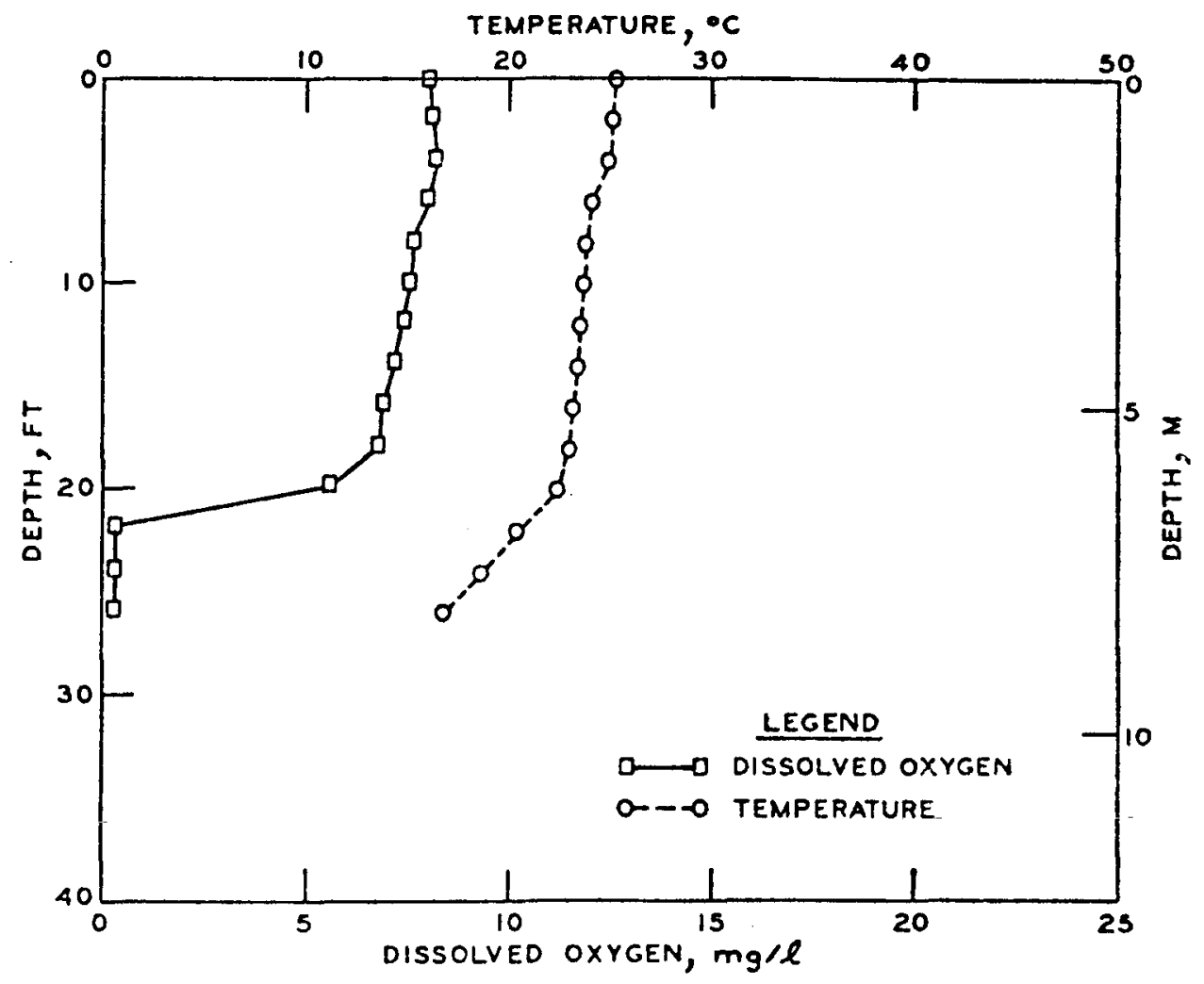

Figure 3. Piedmont Lake temperature-dissolved oxygen profile, $15 \mathrm{JuI} 1976$ 


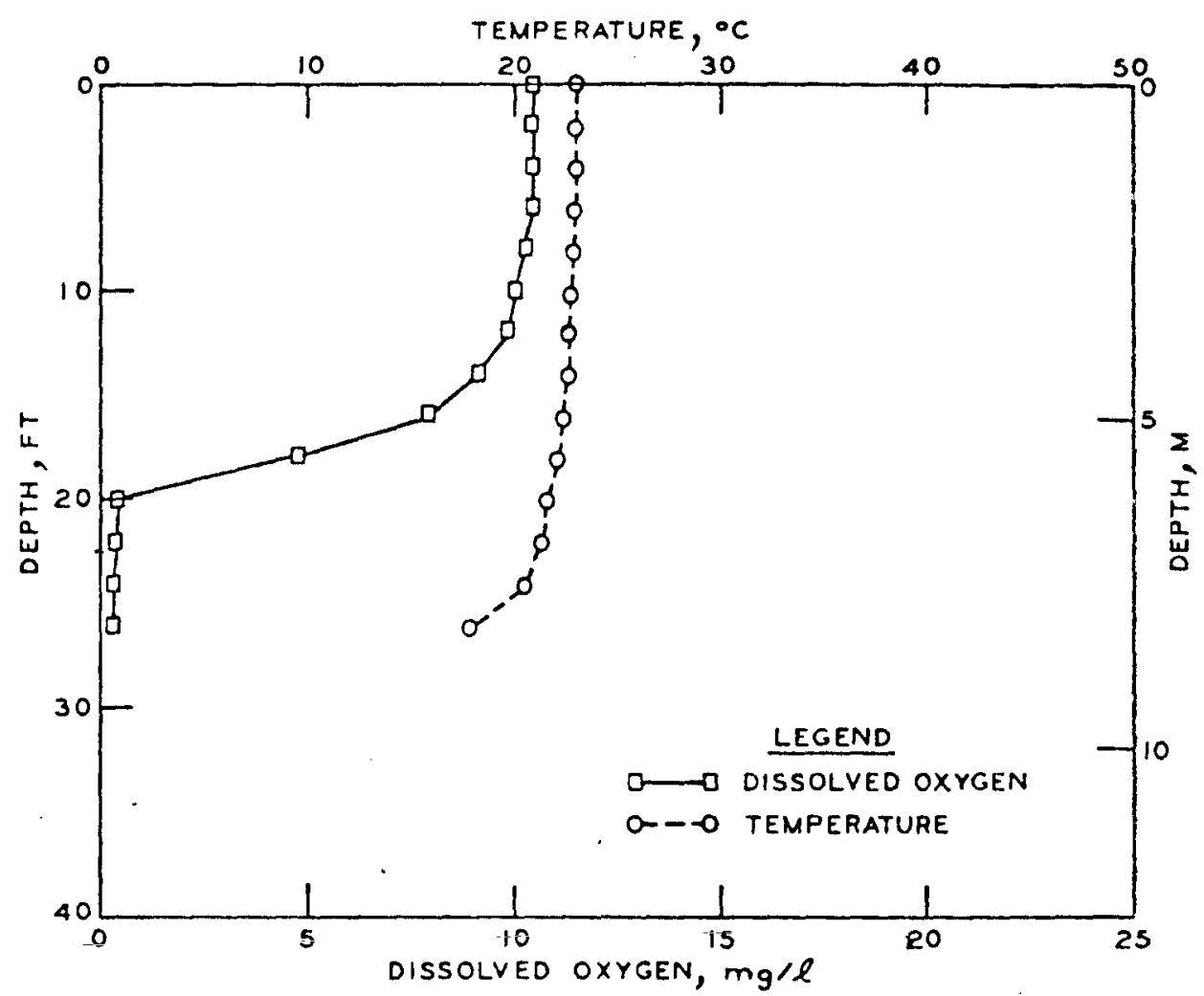

Figure 4. Piedmont Lake temperature-dissolved oxygen profile, 19 Aug 1976 


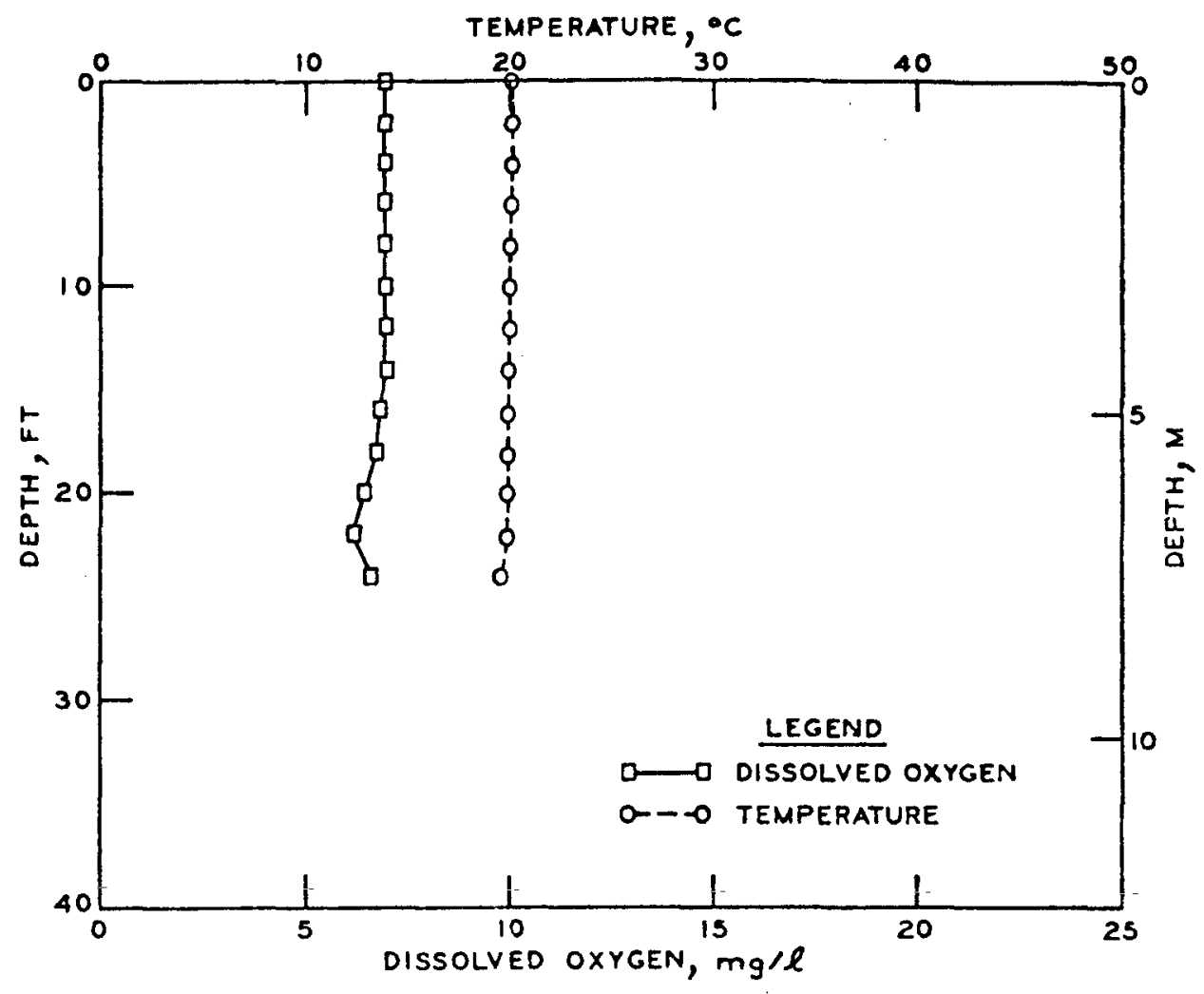

Figure 5. Piedmont Lake temperature-dissolved oxygen profile, 22 sep 1976 


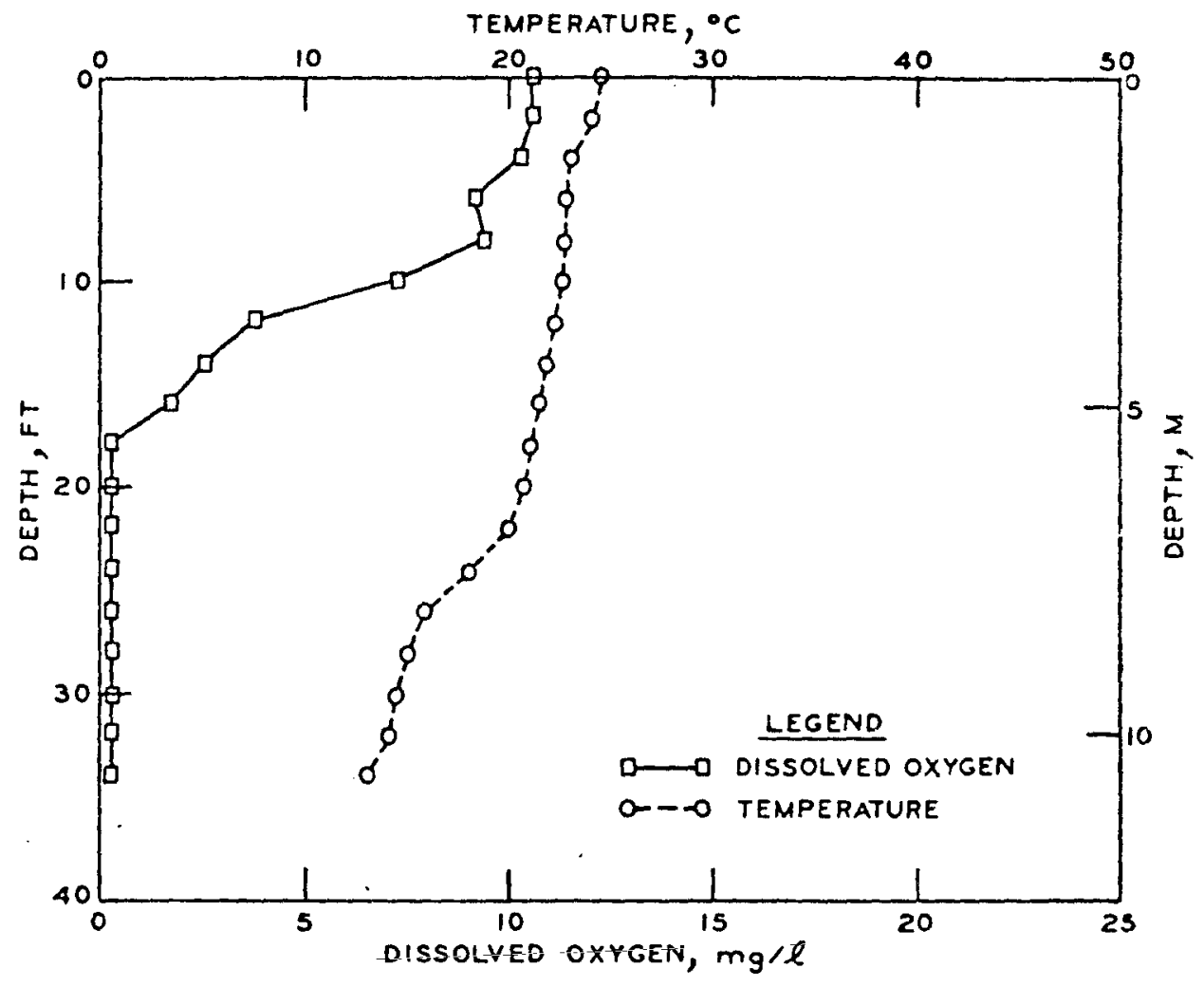

Figure 6. Clendening Lake temperature-dissolved oxygen profile, $14 \mathrm{Jul} 1976$ 


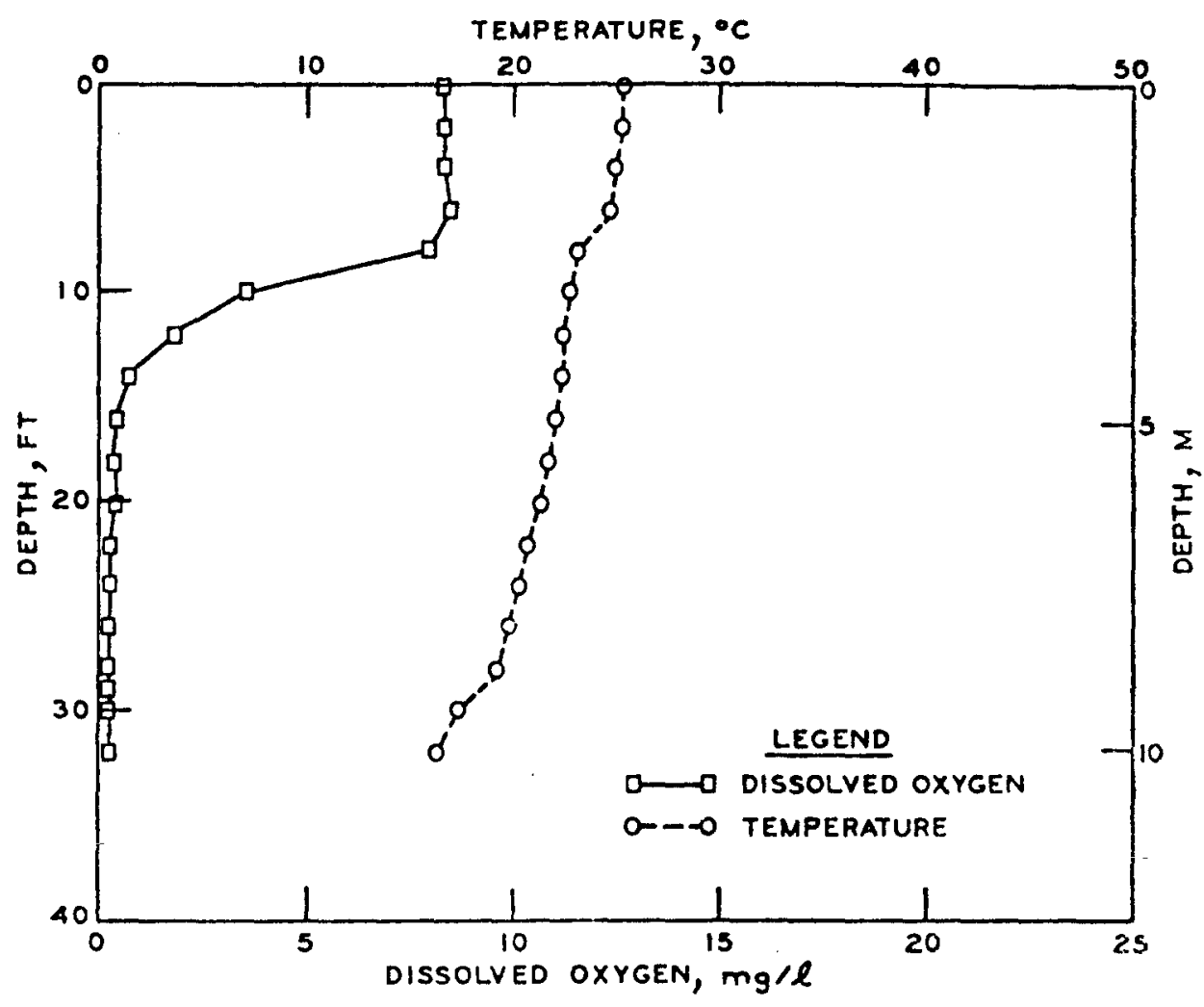

Figure 7. Clendening Lake temperature-dissolved oxygen profile, 18 Aug 1976 


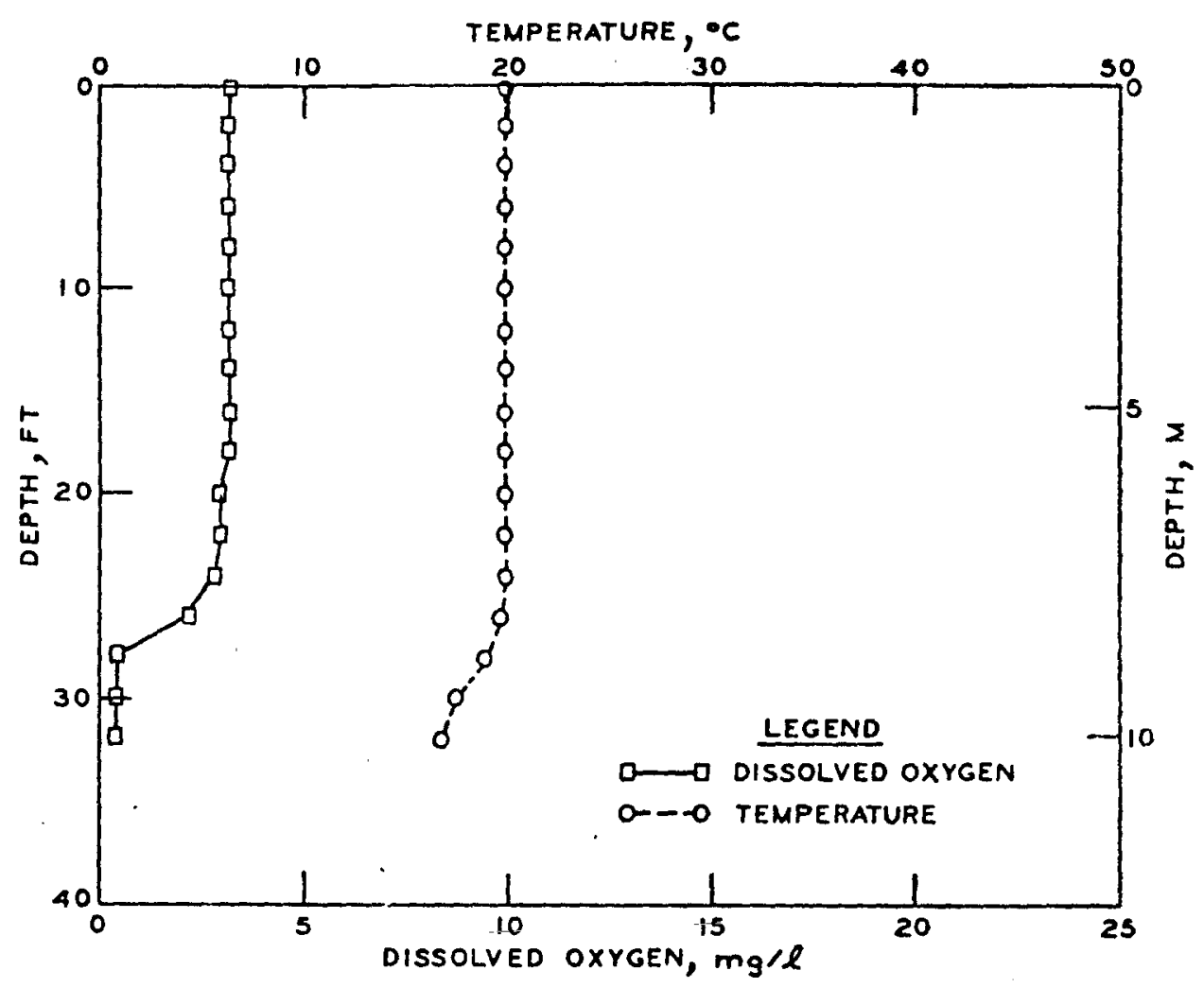

Figure 8. Clendening Lake temperature-dissolved oxygen profile, 22 Sep 1976 
In accordance with letter from DAEN-RDC, DAEN-ASI dated 22 July 1977, Subject: Facsimile Catalog Cards for Laboratory Technical Publications, a facsimile catalog card in Library of Congress MARC format is reproduced below.

Thornton, Henry $T$

Acid attack of concrete caused by sulfur bacteria action / by Henry T. Thornton, Jr. Vicksburg, Miss. : U. S. Waterways Experiment Station ; Springfield, Va. : available from National Technical Information Service, 1978.

17, [7] p. : ill.; $27 \mathrm{~cm}$. (Miscellaneous paper - U. S. Army Engineer Waterways Experiment Station ; C-78-14)

Prepared for U. S. Army Engineer District, Huntington, Huntington, W. Va.

CTIAC Report No. 28 .

References: p. 16-17.

1. Acid attack. 2. Bacteriological tests. 3. Chemical tests. 4. Concrete deterioration. 5. Corrosion. 6. Dissolved oxygen. 7. Hydrogen sulfide. 8. Hypolimnion. 9. Physical tests. 10. Sulfates. 11. Sulfides. 12. Sulfur bacteria. 13. Sulfuric acid. 14. Thermal stratification. I. United States. Army. Corps of Engineers. Huntington District.

II. Series: United States. Waterways Experiment Station, Vicksburg, Miss. Miscellaneous paper ; C-78-14. TA7.W34m no.C-78-14 